\title{
COMPARISON OF THE THERMAL CONDUCTIVITY TO THE GEO-TECHNICAL PROPERTIES OF SOIL FOR THE UNDERGROUND POWER TRANSMISSION PROJECTS
}

\begin{abstract}
Ankit Kumar
Geo-technical Department

Gaveshana Geosciences Pvt Ltd New Delhi, India

Abstract - Underground Power Transmission connectivity projects are going on maximum number of times now a days. The present studies are based on to calculated suitable materials for these types of project. After performing a series of laboratory test, it is observed that well graded soil is suitable material for underground laying of cable. Its transfer heat particles to particles to avoid damage of cable due to heat problem of cable, when high voltage electricity is transferred in the cable. The all laboratory tests are performed as per American Society for Testing and Materials (ASTM) and laboratory test results shown in this paper.
\end{abstract}

Keywords - TLS 100, Thermal Conductivity, Grain Size Analysis, Geo-technical

\section{INTRODUCTION}

Industrialization and urbanization increasing day by day in a country, where electricity connectivity is growing up year by year. For this purpose, so many projects are executing, which require lot of wire connectivity under the ground. These electric wire supply heavy electric conductivity in many areas, which heated due to high voltage of supply. This heated activity cause damage of wire cable, if heats do not transfer regularly. Many project leaders choose a suitable material for underground power transmission. The knowledge of Geophysics many researchers conduct thermal conductivity test on those materials, which are fill up on the ground during laying of underground water. Thermal Conductivity test suggests that material is suitable for or not. If the particles of material well compacted then the wire heat easily transferred one particle to another, but if there is exist gap between the particles i.e. air voids then heat can't be easily transferred particle to particle. One more thing that if the quantity of moisture content or water content is in the fill materials then that also be affect the conductivity of heat.

\author{
Sushil Kumar \\ Geophysicist Department \\ Gaveshana Geosciences Pvt Ltd New Delhi, India
}

Present studies are based on these heat problems of underground transmission of cable. In present work we conducted Geo-technical laboratory testing and found the effect of conductivity on different type of soil. By the use of Geo-technical laboratory testing we can offer a suitable material for those projects, which I have discussed above, and we can generate a suitable material for fill up the ground. The present studies are based on laboratory work, which is based on the knowledge of Geo-technical and Geo-physics studies.

\section{MATERIALS \& METHODS}

Present studies are based on the comparison of material test using TLS 100 system and Sieve Analysis, however other soil tests were performed in the lab to find put the basic properties of soil. The details of methods are described as:

\section{A. Materials -}

The martials obtained for these studies from the river side of Dehradun District, Uttarakhand (India). This material was the mixture of soil, silt, clay and sand, which was in wet condition. The sample collected and put on the oven for 24 hrs. for drying purpose. Before sampling the material, the materials compact by the wooden hammer, which removes all lumps of material for testing purpose.

\section{B. Methods -}

1. Thermal Conductivity Test: Thermal Conductivity test conducted using TLS 100 system and the standard method follows as per ASTM D 5334-14. The tests performed on different size of soil particles and the mixture of different size of particles. The Equipment features has the following salient features:

\section{EQUIPMENT FEATURES}

Materials: Soil, Rock, Concrete, \& Polymers Measurement Time: 5 minutes each measurement Accuracy: Typically, better than 5\% 
Power: 4 AA type Lithium-ion Battery

Operating environment:

Controller: $\quad 0$ to $50^{\circ} \mathrm{C}$,

Sensor: $\quad-40$ to $100{ }^{\circ} \mathrm{C}$

Range of measurement:

K (Thermal Conductivity): $0.1-5 \mathrm{~W} / \mathrm{m}-\mathrm{K}$

$\mathbf{R}$ (Thermal resistivity): 0.2 to $10 \mathrm{~m}-\mathrm{K} / \mathrm{W}$

Sensor:
Needle length:
$100 \mathrm{~mm}$
Needle diameter:
$2.00 \mathrm{~mm}$
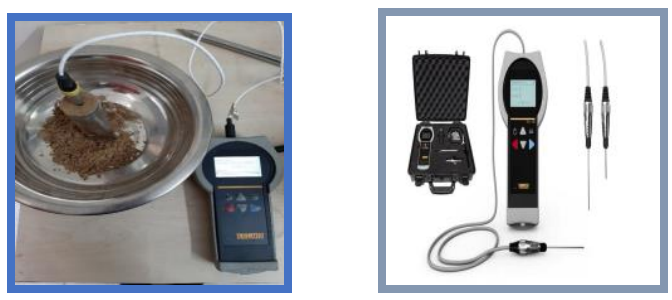

Figure1. TLS 100 System

2. Grain Size Analysis: Grain Size analysis of soil test determine the size of materials and the test conducts using different size of sieve in the laboratory. The standard test follows as per ASTM D422 for dry materials.

3. Atterberg limits: As per ASTM D4318 liquid limit, plastic limit and shrinkage limit were conducted on soil materials for finding out Atterberg limits.

4. Specific gravity: Specific gravity test was conducted as per ASTM D854 by pycnometer apparatus on the soil sample.
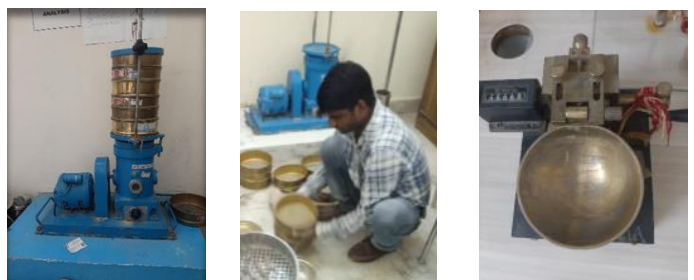

Figure 2. Laboratory set-up of Soil Testing

\section{EXPERIMENT AND RESULT}

1. Geotechnical Properties of Soil: The laboratory test performed on the sample as per the ASTM's guidelines. The test results of materials are tabulated as follows:

Table -1 Geotechnical Properties of Soil

\begin{tabular}{|c|c|c|c|}
\hline S. No. & Parameter & Test Method & Results \\
\hline 1. & $\begin{array}{c}\text { Soil Type as Per } \\
\text { IS: } 1498\end{array}$ & ASTM D2487 & Silty Clay \\
\hline 2. & Liquid Limit & ASTM D4318 & $18.36 \%$ \\
\hline
\end{tabular}

\begin{tabular}{|c|c|c|c|}
\hline 3. & Plastic Limit & ASTM D4318 & $11.62 \%$ \\
\hline 4. & Plasticity Index & ASTM D4318 & $6.74 \%$ \\
\hline 5. & Shrinkage Limit & ASTM D4943 & $14.56 \%$ \\
\hline 6. & Specific gravity & ASTM D854 & 2.67 \\
\hline
\end{tabular}

2. Thermal conductivity of different type of Soil: TLS 100 system was used to calculate thermal conductivity in the laboratory of different size of soil particles. The lab results are shown as follows:

a. When soil particles are lies between $4.75 \mathrm{~mm}$ to $2.36 \mathrm{~mm}$ : The results of thermal conductivity of soil particles between $4.75 \mathrm{~mm}$ to $2.36 \mathrm{~mm}$ are shows in following table:

Table -2 When soil particles are lies between $4.75 \mathrm{~mm}$ to $2.36 \mathrm{~mm}$

\begin{tabular}{|c|c|c|c|c|c|}
\hline $\begin{array}{c}\text { S. } \\
\text { No. }\end{array}$ & $\begin{array}{c}\text { Moisture } \\
\text { Content } \\
(\%)\end{array}$ & $\begin{array}{c}\text { Humidity } \\
(\%)\end{array}$ & $\begin{array}{c}\text { Temp } \\
\left({ }^{\circ} \mathbf{C}\right)\end{array}$ & $\begin{array}{c}\text { Thermal } \\
\text { Conductivity } \\
\text { (W/m-K) }\end{array}$ & $\begin{array}{c}\text { Thermal } \\
\text { Resistivity } \\
(\mathbf{m}-\mathbf{K} / \mathbf{W})\end{array}$ \\
\hline 1. & $\begin{array}{c}\text { Dry } \\
\text { Condition }\end{array}$ & 66 & 13.9 & 0.488 & 2.048 \\
\hline 2. & $\begin{array}{c}5 \% \\
\text { Water } \\
\text { Added to } \\
\text { the } \\
\text { sample }\end{array}$ & 65 & 10.1 & 0.769 & 1.300 \\
\hline 3. & $\begin{array}{c}15 \% \\
\text { Water } \\
\text { Added to } \\
\text { the } \\
\text { sample }\end{array}$ & 67 & 9.9 & 1.087 & 0.920 \\
\hline
\end{tabular}

b. When soil particles are lies between $2.36 \mathrm{~mm}$ to $1.18 \mathrm{~mm}$ : The results of thermal conductivity of soil particles between $2.36 \mathrm{~mm}$ to $1.18 \mathrm{~mm}$ are shows in following table:

Table-3 When soil particles are lies between $2.36 \mathrm{~mm}$ to $1.18 \mathrm{~mm}$

\begin{tabular}{|c|c|c|c|c|c|}
\hline $\begin{array}{c}\text { S. } \\
\text { No. }\end{array}$ & $\begin{array}{c}\text { Moisture } \\
\text { Content } \\
(\%)\end{array}$ & $\begin{array}{c}\text { Humidity } \\
(\%)\end{array}$ & $\begin{array}{c}\text { Temp } \\
\left({ }^{\circ} \mathbf{C}\right)\end{array}$ & $\begin{array}{c}\text { Thermal } \\
\text { Conductivity } \\
(\mathbf{W} / \mathbf{m}-\mathbf{K})\end{array}$ & $\begin{array}{c}\text { Thermal } \\
\text { Resistivity } \\
(\mathbf{m}-\mathbf{K} / \mathbf{W})\end{array}$ \\
\hline 1. & $\begin{array}{c}\text { Dry } \\
\text { Condition }\end{array}$ & 65 & 13.7 & 0.477 & 2.095 \\
\hline 2. & $\begin{array}{c}10 \% \\
\text { Water } \\
\text { Added to } \\
\text { the } \\
\text { sample }\end{array}$ & 66 & 9.5 & 0.895 & 1.117 \\
\hline 3. & $\begin{array}{c}20 \% \\
\text { Water } \\
\text { Added to } \\
\text { the } \\
\text { sample }\end{array}$ & 63 & 9.3 & 1.109 & 0.902 \\
\hline
\end{tabular}

c. When soil particles are lies between $1.18 \mathrm{~mm}$ to 425 microns: The results of thermal conductivity of soil particles between $1.18 \mathrm{~mm}$ to 425 microns are shows in following table: 
Table-4 When soil particles are lies between $1.18 \mathrm{~mm}$ to 425 microns

\begin{tabular}{|c|c|c|c|c|c|}
\hline $\begin{array}{c}\text { S. } \\
\text { No. }\end{array}$ & $\begin{array}{c}\text { Moisture } \\
\text { Content } \\
(\%)\end{array}$ & $\begin{array}{c}\text { Humidity } \\
(\boldsymbol{\%})\end{array}$ & $\begin{array}{c}\text { Temp } \\
\left({ }^{\circ} \mathbf{C}\right)\end{array}$ & $\begin{array}{c}\text { Thermal } \\
\text { Conductivity } \\
(\mathbf{W} / \mathbf{m}-\mathbf{K})\end{array}$ & $\begin{array}{c}\text { Thermal } \\
\text { Resistivity } \\
(\mathbf{m}-\mathbf{K} / \mathbf{W})\end{array}$ \\
\hline 1. & $\begin{array}{c}\text { Dry } \\
\text { Condition }\end{array}$ & 67 & 13.6 & 0.527 & 1.898 \\
\hline 2. & $\begin{array}{c}10 \% \\
\text { Water } \\
\text { Added to } \\
\text { the } \\
\text { sample }\end{array}$ & 68 & 9.6 & 0.785 & 1.273 \\
\hline 3. & $\begin{array}{c}20 \% \\
\text { Water } \\
\text { Added to } \\
\text { the } \\
\text { sample }\end{array}$ & 63 & 9.2 & 1.008 & 0.992 \\
\hline
\end{tabular}

d. When soil particles are lies between $\mathbf{4 2 5}$ microns to 150 microns: The results of thermal conductivity of soil particles between 425 microns to 150 microns are shows in following table:

Table- 5 When soil particles are lies between 425 microns to 150 microns

\begin{tabular}{|c|c|c|c|c|c|}
\hline S. & $\begin{array}{c}\text { Moisture } \\
\text { Content } \\
(\boldsymbol{\%})\end{array}$ & $\begin{array}{c}\text { Humidity } \\
(\boldsymbol{\%})\end{array}$ & $\begin{array}{c}\text { Temp } \\
\left({ }^{\circ} \mathbf{C}\right)\end{array}$ & $\begin{array}{c}\text { Thermal } \\
\text { Conductivity } \\
(\mathbf{W} / \mathbf{m}-\mathbf{K})\end{array}$ & $\begin{array}{c}\text { Thermal } \\
\text { Resistivity } \\
(\mathbf{m}-\mathbf{K} / \mathbf{W})\end{array}$ \\
\hline 1. & $\begin{array}{c}\text { Dry } \\
\text { Condition }\end{array}$ & 67 & 13.8 & 0.488 & 2.048 \\
\hline 2. & $\begin{array}{c}10 \% \\
\text { Water } \\
\text { Added to } \\
\text { the } \\
\text { sample }\end{array}$ & 61 & 10.2 & 0.886 & 1.129 \\
\hline 3. & $\begin{array}{c}20 \% \\
\text { Water } \\
\text { Added to } \\
\text { the } \\
\text { sample }\end{array}$ & 69 & 9.9 & 0.989 & 1.011 \\
\hline
\end{tabular}

e. When soil particles are lies between 150 microns to 75 microns: The results of thermal conductivity of soil particles between 150 microns to 75 microns are shows in following table:

Table-6 When soil particles are lies between 150 microns to 75 microns

\begin{tabular}{|c|c|c|c|c|c|}
\hline $\begin{array}{c}\text { S. } \\
\text { No. }\end{array}$ & $\begin{array}{c}\text { Moisture } \\
\text { Content } \\
(\%)\end{array}$ & $\begin{array}{c}\text { Humidity } \\
(\boldsymbol{\%})\end{array}$ & $\begin{array}{c}\text { Temp } \\
\left({ }^{\circ} \mathbf{C}\right)\end{array}$ & $\begin{array}{c}\text { Thermal } \\
\text { Conductivity } \\
(\mathbf{W} / \mathbf{m}-\mathbf{K})\end{array}$ & $\begin{array}{c}\text { Thermal } \\
\text { Resistivity } \\
(\mathbf{m}-\mathbf{K} / \mathbf{W})\end{array}$ \\
\hline 1. & $\begin{array}{c}\text { Dry } \\
\text { Condition }\end{array}$ & 65 & 13.8 & 0.547 & 1.825 \\
\hline 2. & $\begin{array}{c}10 \% \\
\text { Water } \\
\text { Added to } \\
\text { the } \\
\text { sample }\end{array}$ & 66 & 9.8 & 0.889 & 1.125 \\
\hline 3. & $20 \%$ & 63 & 9.3 & 1.001 & 0.999 \\
\hline
\end{tabular}

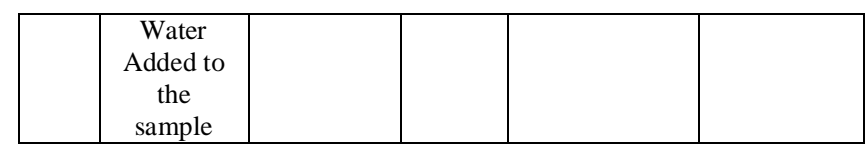

f. When soil is well graded (All Soil size particles mixed mixed): The results of thermal conductivity of soil particles between 150 microns to 75 microns are shows in following table:

Table-6 When soil is well graded (All Soil size particles mixed mixed)

\begin{tabular}{|c|c|c|c|c|c|}
\hline $\begin{array}{c}\text { S. } \\
\text { No. }\end{array}$ & $\begin{array}{c}\text { Moisture } \\
\text { Content } \\
(\boldsymbol{\%})\end{array}$ & $\begin{array}{c}\text { Humidity } \\
(\boldsymbol{\%})\end{array}$ & $\begin{array}{c}\text { Temp } \\
\left({ }^{\circ} \mathbf{C}\right)\end{array}$ & $\begin{array}{c}\text { Thermal } \\
\text { Conductivity } \\
(\mathbf{W} / \mathbf{m}-\mathbf{K})\end{array}$ & $\begin{array}{c}\text { Thermal } \\
\text { Resistivity } \\
(\mathbf{m}-\mathbf{K} / \mathbf{W})\end{array}$ \\
\hline 1. & $\begin{array}{c}\text { Dry } \\
\text { Condition }\end{array}$ & 62 & 13.5 & 0.733 & 1.363 \\
\hline 2. & $\begin{array}{c}5 \% \\
\text { Water } \\
\text { Added to } \\
\text { the } \\
\text { sample }\end{array}$ & 65 & 10.4 & 0.989 & 1.011 \\
\hline 3. & $\begin{array}{c}15 \% \\
\text { Water } \\
\text { Added to } \\
\text { the } \\
\text { sample }\end{array}$ & 63 & 9.8 & 1.342 & 0.745 \\
\hline
\end{tabular}

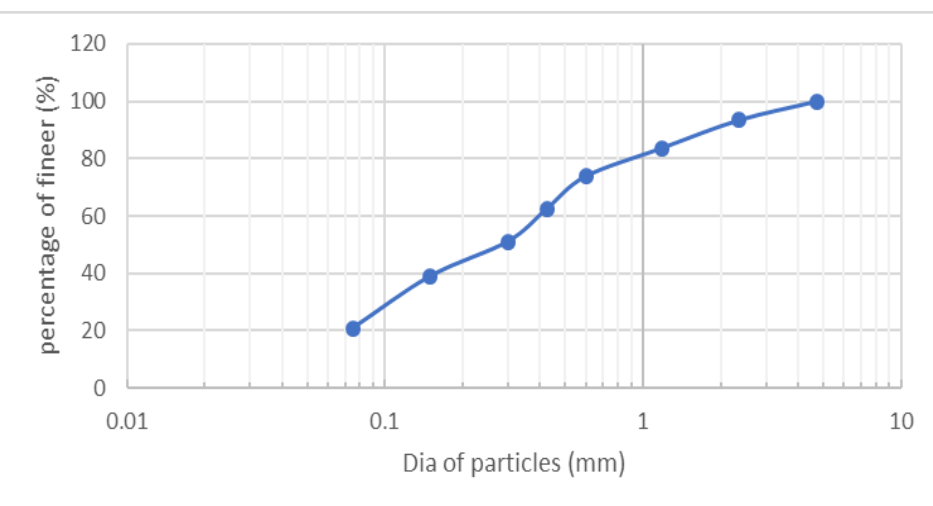

Figure3: Graphical representation of grain size distribution curve of well graded soil

\section{CONCLUSION}

After conducting a series of tests, it is observed that the well graded soil having good properties of heat transfer particles to particles because there are negligible void available between the particles of soil. In present work the soil having $20.20 \%$ of soil and clay, while rest of $79.8 \%$ particle were sand. The well graded soil given the $0.745 \mathrm{~m}-\mathrm{K} / \mathrm{W}$ value of thermal resistivity at $15 \%$ moisture content. It means water filled rest of voids and given proper conductivity to the materials. The summarized results of above work are found that if we have well graded soil materials then no need of 


\section{International Journal of Engineering Applied Sciences and Technology, 2020 \\ Vol. 4, Issue 10, ISSN No. 2455-2143, Pages 174-177 \\ Published Online February 2020 in IJEAST (http://www.ijeast.com)}

further test of materials required. While at dry condition the resistivity is found in high values which can damaged power transmission cable, so it also noticed that the moisture content of materials also effects the thermal conductivity of Soil.

\section{REFERENCE}

[1]. Gou J., Dai Y., Li S., \& Tao, W. (2015). "International Journal of Heat and Mass Transfer Numerical study of effective thermal conductivities of plain-woven composites by unit cells of different sizes". HEAT AND MASS TRANSFER, 91, 829-840. doi:10.1016/j.ijheatmasstransfer.2015.07.074

[2]. Zain-ul-abdein M., Raza K., Ahmad F., \& Mabrouki T. (2015). "Numerical investigation of the effect of interfacial thermal resistance upon the thermal conductivity of copper / diamond composites". JMADE, 86, 248-258. doi:10.1016/j.matdes.2015.07.059

[3]. Zhou Y., Hyuga H., Kusano D., Yoshizawa Y., Ohji T., \& Hirao K. (2015). "Journal of Asian Ceramic Societies Development of high-thermal-conductivity silicon nitride ceramics". Integrative Medicine Research, 3(3), 221-229. doi:10.1016/j.jascer.2015.03.003

[4]. Patel R., Patel C., Patel P. (2016). "Review Paper on MEASURE THERMAL CONDUCTIVITY". JETIR (ISSN2349-5162) February 2016, Volume 3, Issue 2, Page 51-53

[5]. Al Nakshabandi G., and Kohnke H. (1965). "Thermal conductivity and diffusivity of soils as related to moisture tension and other physical properties". Agric. Meteor., 2, 271-279.

[6]. Johansen O., (1975). "Thermal conductivity of soils". Ph.D. thesis, University of Trondheim, 236 pp. [Available from Universitets - biblioteket $i$ Trondheim, Hogskoleringen 1, 7034 Trondheim,Norway.]

[7]. Kersten M. S. (1949). "Thermal properties of soils". University of Minnesota Engineering Experiment Station Bulletin 28, 227 pp. [Available from University of Minnesota Agricultural Experiment Station, St. Paul, MN 55108.

[8]. Gori F. (1983). "A theoretical model for predicting the effective thermal conductivity of unsaturated frozen soils", In: Proc. of the 4th International Conference on Permafrost, Fairbanks (Alaska), National Academy Press, Washington, D.C, pp. 363-368.

[9]. Nakshabandi G. A. and Konke H. (1965). "Thermal conductivity and diffusivity of soils as related to moisture tension and other physical properties". Agric. Meteorol. 2, 271-279

[10]. Sepaskhah A. R. and Boersma L. (1979). "Thermal conductivity of soils as a function of temperature and water content". Soil Sci. Soc. Am. J. 43, 439-444.

[11]. Tarnawski V. R., Gori F., Wagner B. and Buchan G. D. (2000). "Modeling approaches to predicting thermal conductivity of soils at high temperatures". Int. J. Energy Res. 24, 403-423 